MATEC Web of Conferences 17, 01010 (2014)

DOI: $10.1051 /$ matecconf/ 20141701010

(C) Owned by the authors, published by EDP Sciences, 2014

\title{
Sewerage Proposal for Clan Jetty, Penang
}

\author{
N.F. Nik Abllah ${ }^{1, a}$, N.S. Ghazali ${ }^{2}$. \\ ${ }^{1,2}$ School of Housing, Building and Planning, Universiti Sains Malaysia, 11800, Penang, Malaysia
}

\begin{abstract}
Sewage systems transport sewage through cities and other inhabited areas to sewage treatment plants to protect public health and prevent disease. Sewage is treated to control water pollution before being discharged to surface waters. Sewerage systems are very important for housing areas as they ensure that human waste is disposed of properly and directed to the treatment plant. At Clan Jetty, Penang there is no sewerage system, so human waste is directly disposed of into the water. As a place of historical interest which encourages visitors to come, seeing the human waste floating on the water surface and smelling the dirty water is not good for tourism. The function of a sewerage system is to transfer any wastes such as those that are ordinarily discharged from toilets, water closets, baths, showers, sinks, basins and other sanitary and kitchen fitments. The absence of a proper sewerage system has seriously damaged the beauty of the whole area. The absence of which, combined with general water pollution around Penang, has seriously affected the waters around the jetties which are no longer even suitable for fishing [1]. The main purpose of this thesis is to propose a treatment process and also to recommend long-term operations and maintenance in order to properly deal with the issue of substandard sewage processing.
\end{abstract}

\section{Introduction}

Clan Jetty stands out as a remarkable historical site in George Town, Penang. One of the oldest and best preserved sites in the area, Clan jetty is located along Weld Quay, just a few hundred metres away from the Penang ferry terminal. In total, there are six jetties along Weld Quay, namely, Chew Jetty, Lee Jetty, Lim Jetty, Tan Jetty, Yeoh Jetty and Mixed Surname Jetty. Having been around since the 19th century, clan jetties are unique Chinese settlements with homes built on stilts along wooden piers that extend to the sea or Penang Channel. Today, the residents of each clan jetty are descendants of Chinese immigrants [2].

Because of their long history, the jetties are now located within the core heritage conservation area of George Town (Penang's main city) which has applied for UNESCO World Heritage Listing status. Typically, houses here are supported by wood or cemented beams and stand in a row on one or both sides of a narrow wooden walkway of just a couple metres wide. These single story houses are usually covered by triangular shaped zinc roofs and a slightly elevated porch to park bicycles or motorcycles at door front. At some corners, there are a few alleys leading to more houses ending in cul-de-sacs [3].

This proposal presents the idea of setting up a vacuum sewer system to collect all human waste coming from toilets, showers, kitchens, and washing machines. By doing so, the water will become clean and foul odours will be eliminated [4]. This system requires no electricity, so there are no electrical lines to worry about and the valve will function even during power outages [5]. When 10 gallons of wastewater accumulate in the pit, the

\footnotetext{
${ }^{a}$ Corresponding author : nfuaad@usm.my
} 
valve will open automatically and differential air pressure will propel the contents into the vacuum main. [6]. In Figure 1, the green area represents the focus area of the study and the existing sewer line is shown to the top left.

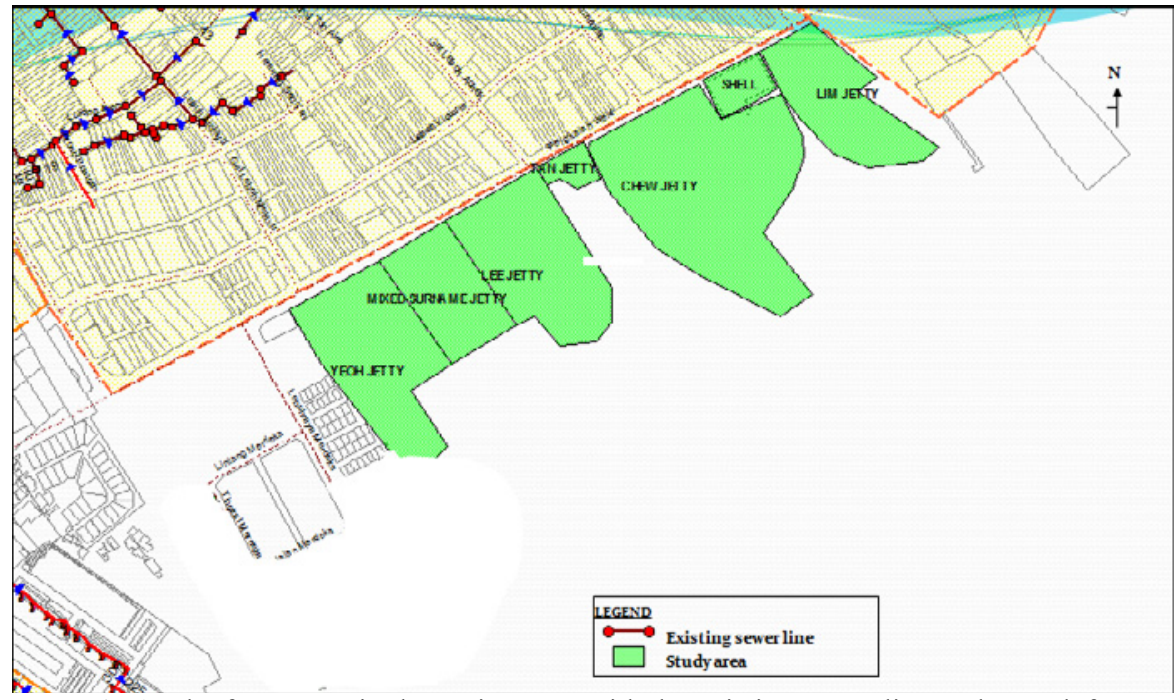

Fig 1: The focus area is shown in green with the existing sewer line at the top left

There are a total of 213 houses at Clan Jetty taking up an area of $2500 \mathrm{~m}$ square. Chew Jetty hosts the highest population and Tan Jetty has the lowest population, mostly because Tan Jetty predominantly houses older residents. The Clan Jetties are situated close to the Penang ferry terminal, with the entrance to the jetties located through the temple on the quayside. Maintaining its heritage value with minimal changes in its physical aspects, the area is not expected to grow in size. The waste in the area not only comes from all of the houses at the jetty, but also from the restaurants nearby the jetty and from the shell station. Oil from the shell station flows to the sea; making the seawater polluted and oily.
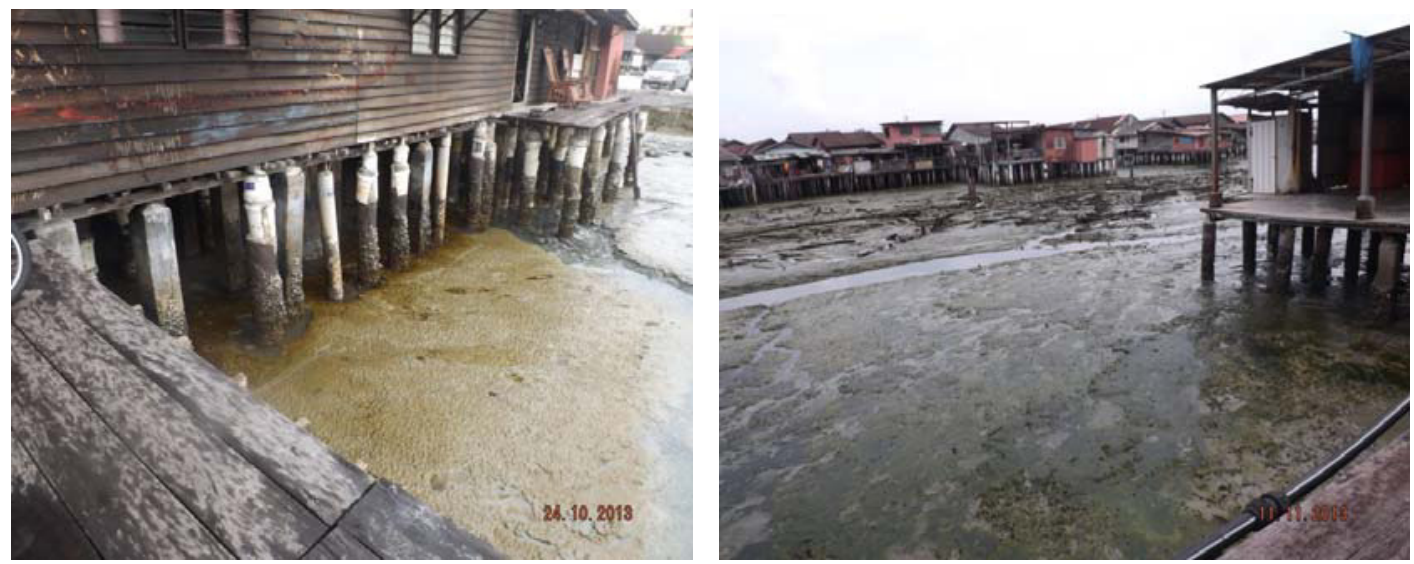

Fig 2: Human waste can be seen floating on the water surface.

The main problem in this area is that there is no sewerage plant to collect and transfer all the human waste. Figure 2 shows how human waste is directly disposed of into the sea which negatively impacts the quality of the water, making it dirty and smelly with profuse algae and microbacteria. Additionally, the people who live in this area commonly face many health problems due to the water pollution. 


\section{Methodology}

The six jetties involved in this study are as follows: Lim Jetty, Chew Jetty, Tan Jetty, Lee Jetty, Mix Surname Jetty and Yeoh Jetty. Based on an observational survey at Clan Jetty, for each jetty, the number of houses, the number of water closets and the occupancy per house were collected in order to determine the design of the PE pipe. For each house, the recommended PE pipe is 5. The calculation for population equivalent served by the completed development in accordance with MS: 1991 and guidelines published by DGSS as follows:

Table 1: Calculation of population equivalent (PE) for Clan Jetty, Penang

\begin{tabular}{|c|c|c|c|c|c|}
\hline Item & $\begin{array}{c}\text { Types of Premises/ } \\
\text { Establishment }\end{array}$ & Unit & $\begin{array}{c}\text { Unit/ Area } \\
\left(\mathbf{N o} / \mathbf{~ m}^{\mathbf{2}}\right)\end{array}$ & $\begin{array}{c}\text { Recommended } \\
\text { P.E }\end{array}$ & PE \\
\hline 1 & Lim Jetty & Unit & 40 & 5 & 200 \\
\hline 2 & Chew Jetty & Unit & 76 & 5 & 380 \\
\hline 3 & Tan Jetty & Unit & 22 & 5 & 110 \\
\hline 4 & Lee Jetty & Unit & 32 & 5 & 160 \\
\hline 5 & Mixed Surname Jetty & Unit & 24 & 5 & 120 \\
\hline 6 & Yeoh Jetty & Unit & 19 & 5 & 95 \\
\cline { 4 - 5 } & & & & Total & 1065 \\
\cline { 3 - 5 } & & & & Design & 1200 \\
\hline
\end{tabular}

As shown in Table 1, the number of houses at Chew Jetty is higher because this jetty is bigger than the others. The least number of houses is at Yeoh Jetty. Therefore, according to the PE from Table 1, the P.E pipes can be designed as explained in section 3 Results and Discussions. As the demography of the study area is unique, a population study was necessary to verify compliance with the national Population Equivalent adopted of 5 P.E. per residential unit. Most, if not all, of the Clan Jetty homes were visited to determine the number of residents, house layout (toilets) and sanitary appliances (types/locations/numbers). In order to design a pipe network, pump stations and sewage treatment plants, estimates had to be made of the volumetric flow rate which is expected to be carried, pumped and treated. Such flow rates are measured in cubic metres per second and needed to be calculated for both existing land use and for expected future development. There are many methods for calculating expected flow rates. One method is to calculate a design parameter called the "population equivalent" (PE) of a catchment and convert this to a flow rate. The PE is an estimate of the usage made of sewage facilities and is not a measure of population. Due to the fact that the study area is in the core zone of the UNESCO World Heritage Site, there cannot be any new physical development. For this reason, the PE of the study area will remain the same as at present. About 70 percent of the 213 Clan Jetty houses and the average occupants per house are close to 5 . Therefore, for the study area, the PE adopted was 5 per house.

\section{Results and Discussion}

The drawing below includes the location of a vacuum chamber (water), collection chamber (water), vacuum and collection chamber (land) and the PE Pipe, uPVC Pipe and Vacuum Station for each jetty. Based on the AutoCAD Clan Jetties Layout Weld Quay drawing in Figure 3, the vacuum station will be located at the centre of all the jetties which is Tan Jetty. All of the waste from each jetty will be pumped into the vacuum station before being released to the existing sewer. This vacuum station will automatically release the waste and will not be overloaded. From the vacuum station, a $150 \mathrm{~mm}$ diameter discharge pipe of $560 \mathrm{~m}$ in length will be used to transfer all of the waste from the vacuum station to the existing sewerage. On the land in front of the road running from Yeoh Jetty, Mixed Surname Jetty, Lee Jetty and Tan Jetty, a PE pipe with a diameter of $160 \mathrm{~mm}$ and a length of 290m will be used. Starting from Tan Jetty and running to Chew Jetty and Lim Jetty, a PE pipe with a $160 \mathrm{~mm}$ diameter and $270 \mathrm{~m}$ length will be used. 


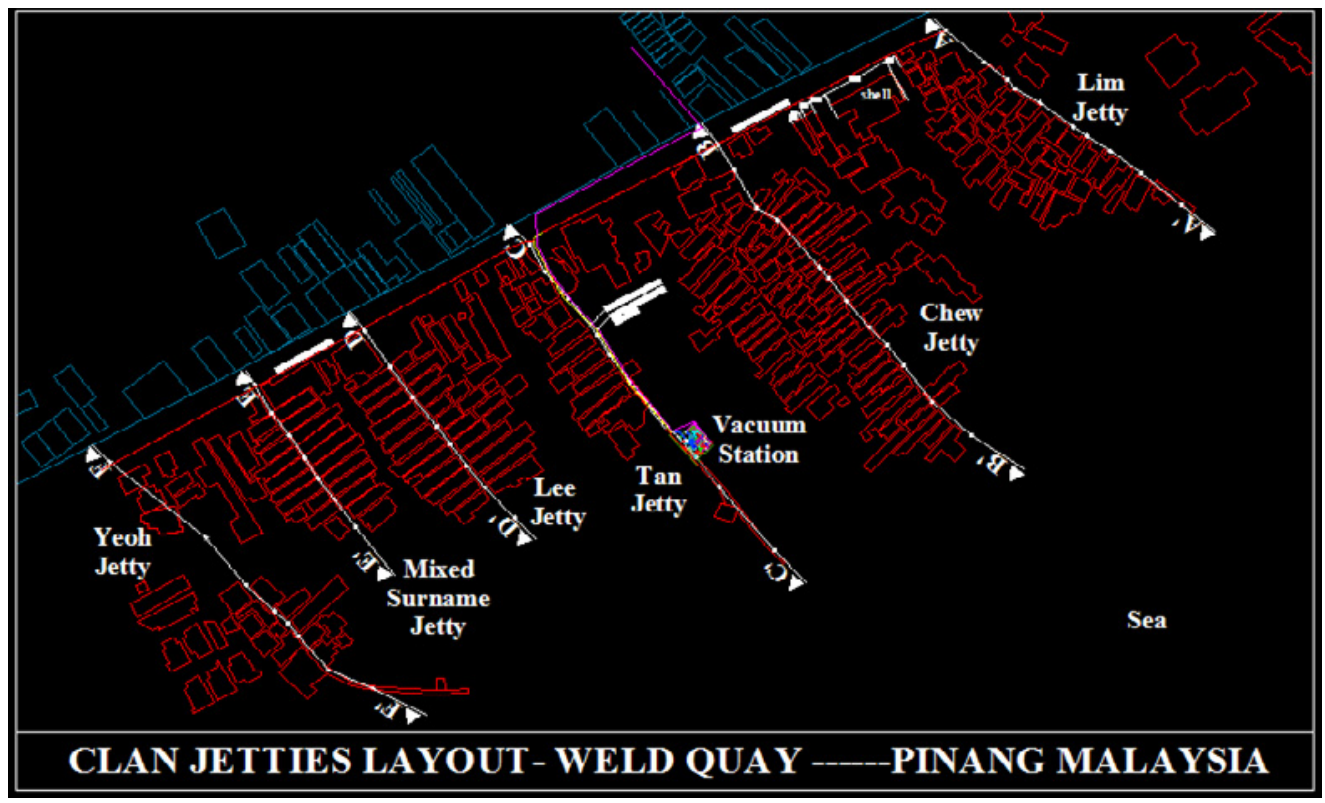

Fig 3: The Layout of Clan Jetty

These PE pipes were chosen because of their excellent resistance to corrosion and stability; they do not require expensive maintenance or cathodic protection. They offer better overall resistance to corrosive acids, bases and salts than most piping materials. In addition, polyethylene is unaffected by bacteria, fungi and the most aggressive naturally occurring soils. It has good resistance to many organic substances, such as solvents and fuels.

A vacuum station functions as a transfer facility between the central collection point for all vacuum sewer lines and a force main leading directly or indirectly to a treatment facility. The wastewater from the vacuum mains empties into the collection tank which is a sealed, vacuum-tight vessel made of carbon steel, fibreglass, or stainless steel. Vacuum gauges are used on all incoming lines to allow the operator to monitor the vacuum levels of each vacuum main. For the Clan Jetties, the vacuum station will need to be erected in the sea because there is no appropriate vacant land in its vicinity. It is proposed that the vacuum station be located somewhere along the walkway of Tan Jetty.

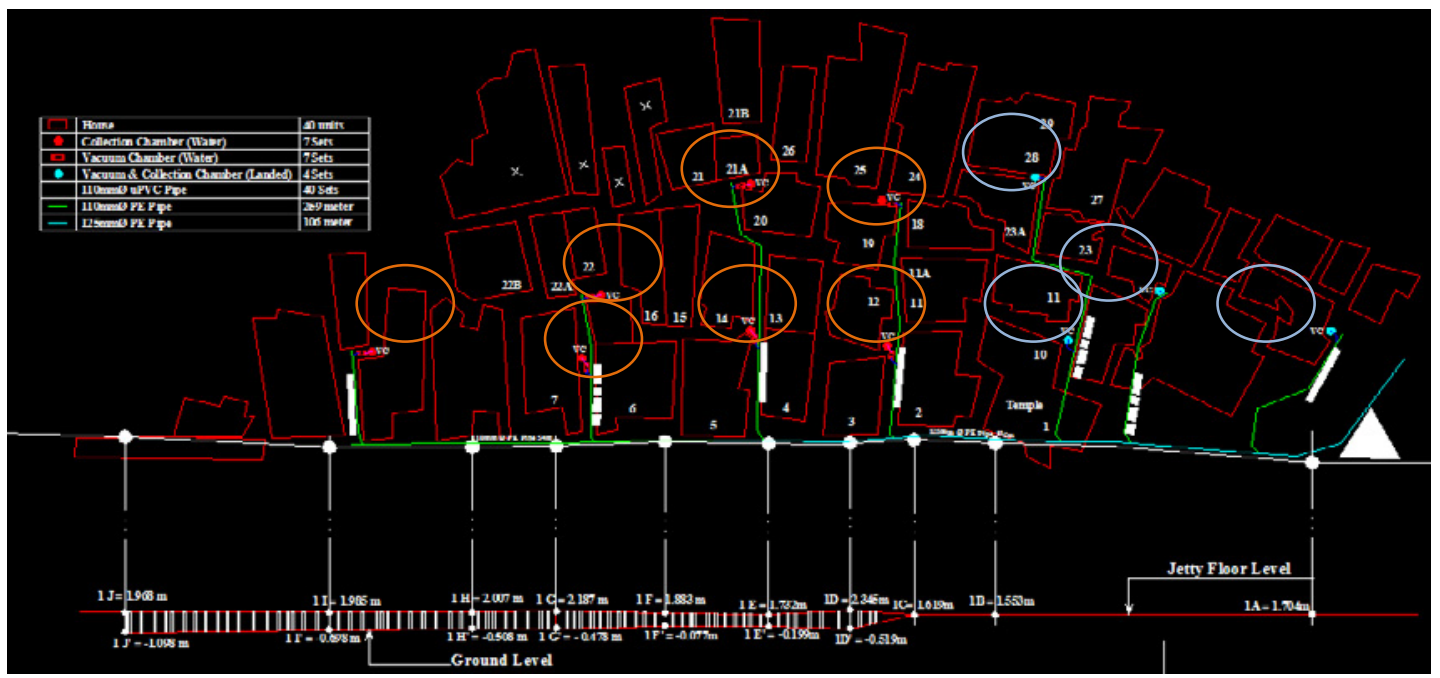

Fig 4: The detailed location of each vacuum chamber and collection chamber at Lim Jetty 
There are 40 housing units at Lim Jetty (Figure 4). The types of piping to be used at this site are $110 \mathrm{~mm}$ diameter PE pipe with a total length of $259 \mathrm{~m}$ as well as $125 \mathrm{~mm}$ diameter PE pipe with a total length of $106 \mathrm{~m}$. A total of 7 collection and vacuum chambers will set up in the water at this site as well as 4 sets of landed vacuum and collection chambers. 40 sets of $110 \mathrm{~mm}$ diameter UPVC pipe will be used.

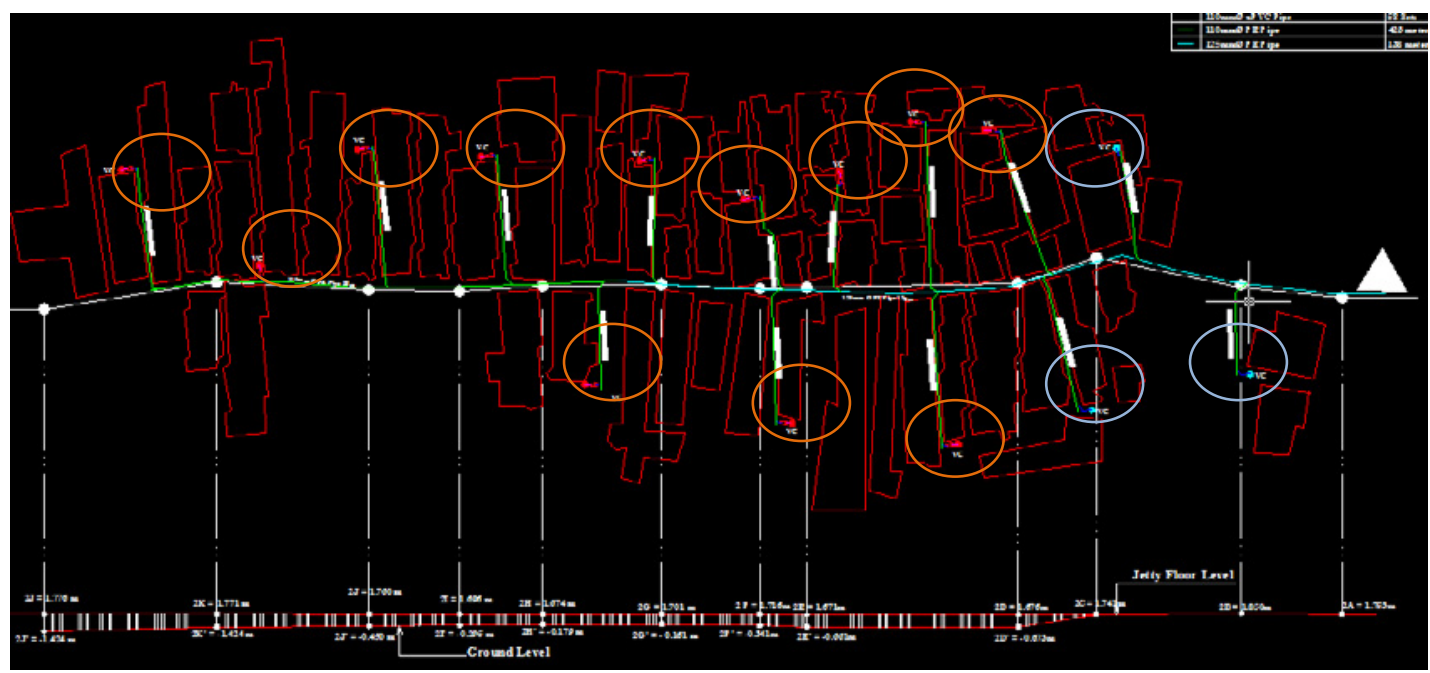

Fig 5: The detailed location of each vacuum chamber and collection chamber at Chew Jetty

There are 76 housing units at Chew Jetty (Figure 5). The types of piping to be used at this site are 110 diameter PE pipe with a total length of $492 \mathrm{~m}$ and $125 \mathrm{~mm}$ diameter PE pipe with a total length of $138 \mathrm{~m}$. The number of collection and vacuum chambers that will set-up in the water at this site are 13 and 17 sets, respectively. There will also be 4 sets of landed vacuum and collection chambers. 76 sets of $110 \mathrm{~mm}$ diameter UPVC pipe will be used.

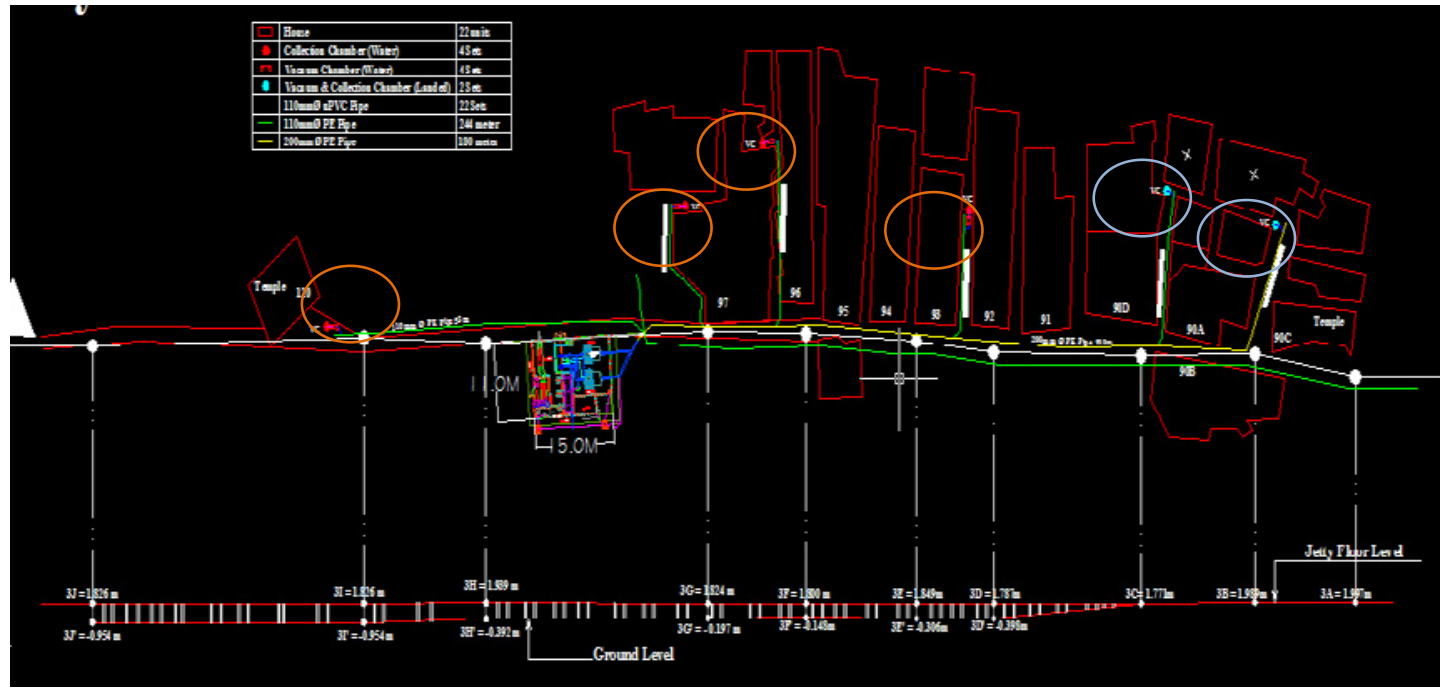

Fig 6: The detailed location of each vacuum chamber and collection chamber at Tan Jetty

At Tan Jetty (Figure 6), there are 22 housing units. The types of piping to be used at this site are $110 \mathrm{~mm}$ diameter PE pipe with a total length of $244 \mathrm{~m}$ and $200 \mathrm{~mm}$ diameter PE pipe with a total 
length of $180 \mathrm{~m} .4$ sets of collection and vacuum chambers will set up in the water at this site as well as 2 sets of landed vacuum and collection chambers. 22 sets of $110 \mathrm{~mm}$ diameter UPVC pipe will be used.

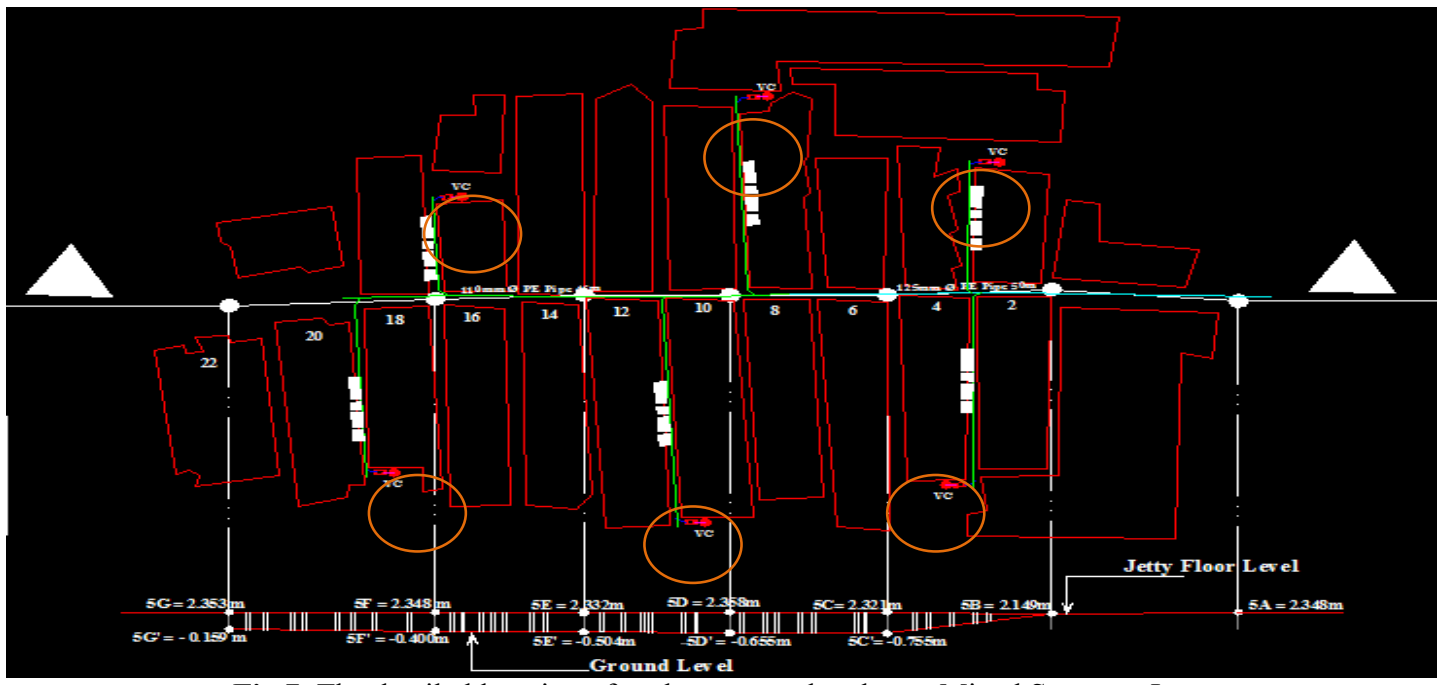

Fig 7: The detailed location of each vacuum chamber at Mixed Surname Jetty

There are 24 housing units at Mixed Surname Jetty (Figure 7). The types of piping to be used at this site are $110 \mathrm{~mm}$ diameter PE pipe with a total length of $204 \mathrm{~m}$ and $125 \mathrm{~mm}$ diameter PE pipe with a total length of $50 \mathrm{~m}$. 6 sets of collection and vacuum chambers will set up in the water at this site with no landed vacuum or collection chambers. 24 sets of $110 \mathrm{~mm}$ diameter UPVC pipe will be used.

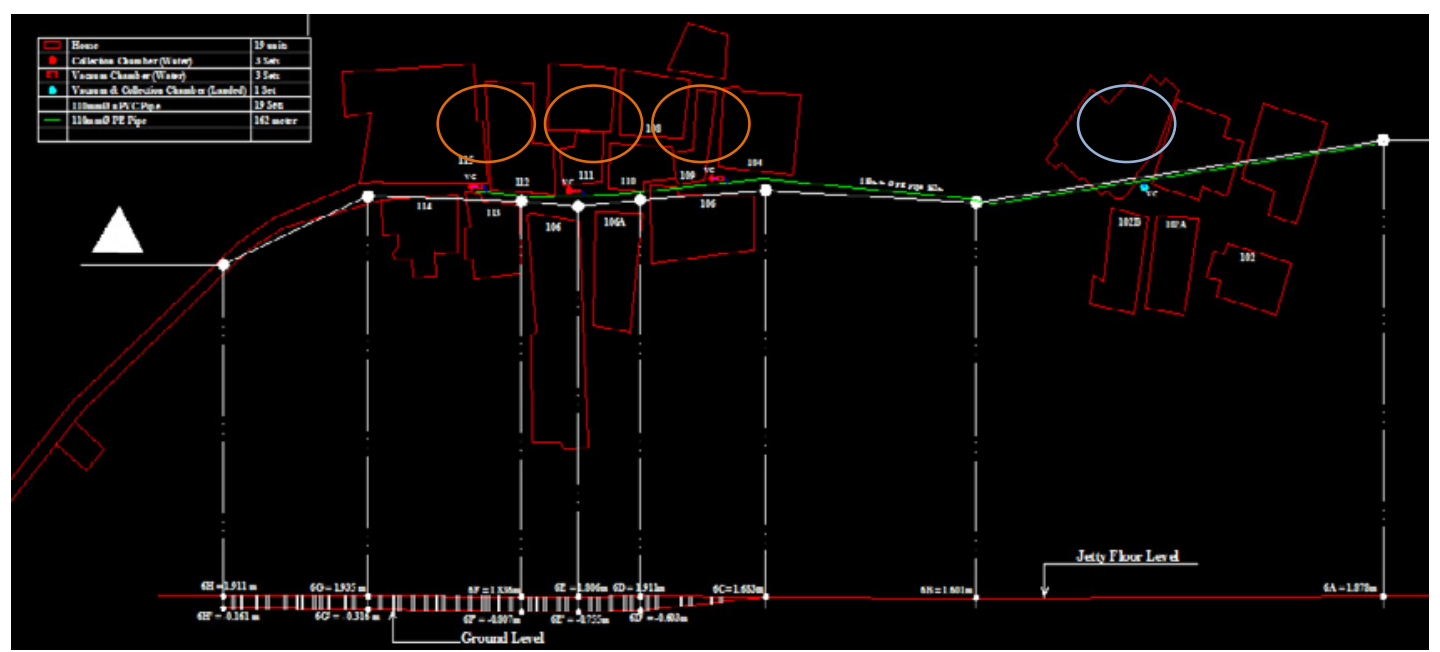

Fig 8: The detailed location of each vacuum chamber and collection chamber at Yeoh Jetty

Yeoh Jetty (Figure 8) has 19 housing units. The type of piping to be used at this site is $110 \mathrm{~mm}$ diameter PE pipe with a total length of $162 \mathrm{~m}$. 3 sets of collection and vacuum chambers will set up in the water at this site as well as 1 set of landed vacuum and collection chambers. 19 sets of $110 \mathrm{~mm}$ diameter UPVC pipe will be used. 


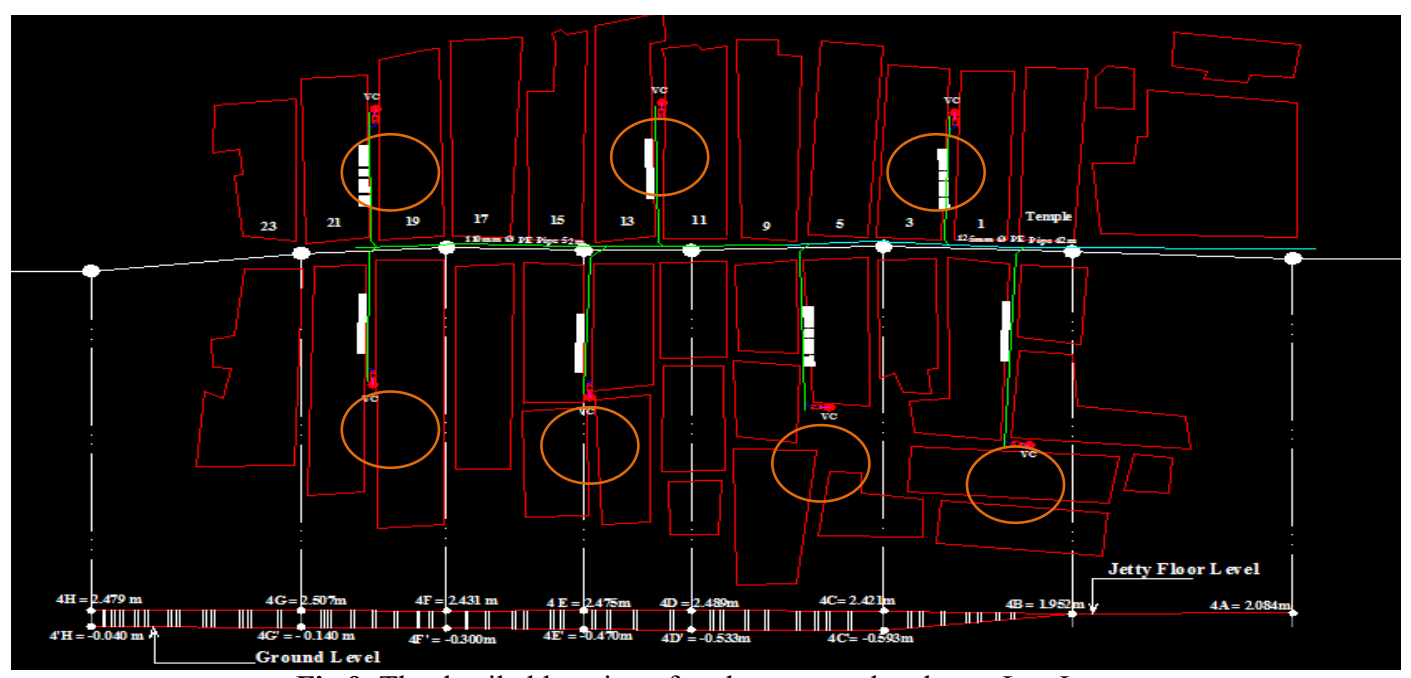

Fig 9: The detailed location of each vacuum chamber at Lee Jetty

Lee Jetty (Figure 9) has 32 housing units. The types of piping to be used at this site are $110 \mathrm{~mm}$ diameter PE pipe with a total length of $219 \mathrm{~m}$ and $125 \mathrm{~mm}$ diameter PE pipe with a total length of $62 \mathrm{~m}$. 7 sets of collection and vacuum chambers will set up in the water at this site with no landed vacuum or collection chambers. 32 sets of $110 \mathrm{~mm}$ diameter UPVC pipe will be used.

\section{Notes:}

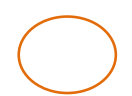

Vacuum and collection chamber (water)

Vacuum and collection chamber (land)

Table 2: Summary of installation elements for vacuum sewerage at Clan Jetty

\begin{tabular}{|c|c|c|c|c|c|c|}
\hline Jetty's Name & Lim Jetty & Chew Jetty & Tan Jetty & $\begin{array}{c}\text { Mixed } \\
\text { Surname } \\
\text { Jetty }\end{array}$ & Yeoh Jetty & Lee Jetty \\
\hline No of houses & 40 & 76 & 22 & 24 & 19 & 32 \\
\hline Types of PE pipe & $\begin{array}{c}110 \mathrm{~mm} \text { and } \\
125 \mathrm{~mm} \\
\text { diameter PE } \\
\text { pipe }\end{array}$ & $\begin{array}{c}110 \mathrm{~mm} \text { and } \\
125 \mathrm{~mm} \\
\text { diameter PE } \\
\text { pipe }\end{array}$ & $\begin{array}{c}110 \mathrm{~mm} \text { and } \\
200 \mathrm{~mm} \\
\text { diameter PE } \\
\text { pipe }\end{array}$ & $\begin{array}{c}110 \mathrm{~mm} \text { and } \\
125 \mathrm{~mm} \\
\text { diameter PE } \\
\text { pipe }\end{array}$ & $\begin{array}{c}110 \mathrm{~mm} \\
\text { diameter PE } \\
\text { pipe }\end{array}$ & $\begin{array}{c}110 \mathrm{~mm} \text { and } \\
125 \mathrm{~mm} \\
\text { diameter PE } \\
\text { pipe }\end{array}$ \\
\hline $\begin{array}{c}\text { Number of } \\
\text { collection } \\
\text { chamber (water) }\end{array}$ & 7 & 13 & 4 & 6 & 3 & 7 \\
\hline $\begin{array}{c}\text { The number of } \\
\text { vacuum chamber } \\
\text { (water) }\end{array}$ & 7 & 17 & 4 & 6 & 3 & 7 \\
\hline $\begin{array}{c}\text { Number of } \\
\text { collection } \\
\text { chamber (land) }\end{array}$ & 4 & 4 & 2 & 0 & 1 & 0 \\
\hline $\begin{array}{c}\text { The number of } \\
\text { vacuum chamber } \\
\text { (land) }\end{array}$ & 4 & 4 & 2 & 0 & 1 & 0 \\
\hline $\begin{array}{c}110 \text { mm diameter } \\
\text { uPVC pipe }\end{array}$ & 40 & 76 & 22 & 24 & 19 & 32 \\
\hline
\end{tabular}


For all six jetties, three types of PE pipe will be used with varying diameters of $100 \mathrm{~mm}, 125 \mathrm{~mm}$ and $200 \mathrm{~mm}$. The number of collection and vacuum chambers to be installed at each jetty is different based on the number of houses located there. The higher the number of houses and water closets, the higher the number of vacuum and collection chambers that will need to be installed. For Mixed Surname Jetty and Lee Jetty, no collection or vacuum chamber will be installed because all the houses there are built on the water. uPVC piping with a diameter of $110 \mathrm{~mm}$ will be used at all of the jetties. uPVC (unplasticized polyvinylchloride) pipes and fittings exhibit excellent resistance to aggressive environments, both naturally occurring and as a result of industrial activity. They are resistant to almost all types of corrosion, either chemical or electrochemical in nature. Since uPVC is a non-conductor, galvanic and electro chemical effects do not occur in UPVC pipes.

\section{Conclusion}

As a conclusion, Clan Jetty requires a systematic sewarage system in order to solve the current water pollution problem and to rid the area of foul odours. To increase tourism, it is essential that a clean, comfortable environment be provided so visitors to the area are satisfied and can enjoy the unique heritage of the area without being distracted by the waste. The implementation of a sewerage system should be provided as soon as possible and may be implemented in phases based on a budget. By doing installation in phases, the workability of the new system can be improved and upgraded in the subsequent phases. Since the houses in the area are built on the ocean floor, the most suitable system to tap the sewage flow from the houses is a Vacuum Sewer System. A comprehensive Vacuum Sewer System is proposed in this Draft Final Report.

Applying a vacuum sewerage system can solve the problems currently faced at Clan Jetty. A modern vacuum system does not rely on gravity to transport sewage and there is no need for deeptrench excavation. Shallow trenching means less heavy equipment and less disruption of neighborhoods and traffic. The design also calls for only one vacuum station, rather than three pumping stations as is needed for a gravity system. In this way, costs can be cut. Gravity lines transport sewage from the home just like they do in a gravity system, but at the street or property line, the sewage empties into a buried valve pit. The total cost for the proposed Vacuum Sewer System for Clan Jetty calculates to a final figure of RM4,503,769.00.

\section{References}

1. Linssen, F., 2012. The Clan Jetties of Penang. p. 2.

2. http://www.asiarediscovery.com/malaysia/101-penang-heritage-weld-quay-chew-jetty-a-clanjetties (Access on 14 December 2013)

3. Chan, Ngai Weng (2011) Challenges in developing Clan Jetties as heritage attractions for conservation and tourism in Penang Malaysian. Malaysian Journal of Environmental Management, 12 (1). pp. 117-127. ISSN 1511-7855.

4. Carl Gaskill, P. E. \& Edwin Masker, Sept 2009. Mayor Tiny Alloway Township Saves Big with Vacuum Sewers.

5. Varis et al. Jan 22, 1980. Vacuum Sewer System.

6. Ushitora et al. Jan 28, 1992. Laying Structure for Vacuum Sewer Pipe of Vacuum Sewage Collecting System. 